\section{Walter Eggert Beach}

With Walter Beach's passing in November 2006, a host of communities lost a valued and dedicated friend. When Walter was presented APSA's Frank J. Goodnow Award in 1998 for his sustained contributions to the discipline, if his political science colleagues who knew him less well were enormously impressed by the vast extent of his civic engagements, they had to be mind-boggled by the depth of his contributions. These contributions went far beyond his 15-year service to APSA as staff associate, director of the Congressional Fellowship Program, and, finally, assistant director; they also included his 10-year engagement at the Brookings Institution, and his 16-year engagement with Heldref Publications and the Helen Dwight Reid Educational Foundation. It was as if Walter never met a worthy endeavor for which he would not become a benefactor-from his life-long commitment to his 1956 alma mater Dickinson College (along with brother Alan, 1955) from which he was given the Distinguished Alumni Award in 1992, to his service as trustee of the Hillwood Museum and Gardens Foundation, to his directorship of the International Eye Foundation, to his endowment of the National Capital Area Political Science Association, to his vigorous support of the Southern Political Science Association, to his service on the board of the Washington Center for Internships, to his fundraising prowess for George Washington University's Gelman Library and Mount Vernon College, among others. These will be the focus of a fuller tribute to be published in the April 2006 issue of PS: Political Science and Politics.

For now, the staff of APSA want to pay tribute to a tireless and loving friend who set the benchmark for what it is to be a colleague. Even if simply delivering a message at our 1527 New Hampshire Avenue offices, Walter could not escape the building in less than an hour because he would stop to chat with each employee, or we with him. Few of us have not received periodic news clippings reminding us of all-but-forgotten members of the political science community that we serve. There was no aspect of our efforts for which he did not have a kind word and helpful contribution. Walter Beach represented the true definition of sui generis-he constituted a class alone.

\section{APSA Staff}

\section{Deborah J. "Misty" Gerner}

Professor Deborah J. Gerner, known to colleagues and friends as "Misty," died on June 19, 2006, at her home in Vinland, Kansas, after a long struggle with cancer.

Gerner earned her doctorate in political science at Northwestern University, and taught at Birzeit University, the University of Iowa, Hamilton College, and the American University in Cairo. In 1988, she joined the department of political science at the University of Kansas, where she eventually became full professor. Her substantive research interests initially focused on arms trade, foreign aid, nationalism, and American foreign policy in the Middle East, and more recently addressed questions of conflict and conflict resolution, human rights, and democratization. Her work in these areas was informed by her expertise in Middle East politics in general and the Palestinian-Israeli conflict in particular. She was author of One Land, Two People: The Conflict over Palestine, published by Westview press in 1980 and updated in a second edition published in 1994, and editor of Understanding the Contemporary Middle East, published by Lynne Rienner in 2000 and revised in 2003 with assistance from Jillian Schwedler. As a member of the Quaker Working Party, Gerner was also a core contributor to When the Rain Returns: Justice and Reconciliation in Palestine and Israel (2004). Her articles have appeared in American Political Science Review, American Journal of Political Science, International Studies Quarterly, and Journal of Conflict Resolution.

Two qualities emerged in Gerner's early work that remained constant throughout her career. First, she stressed the use of multiple methods: neither case studies nor quantitative evidence alone would suffice to adequately explore hypotheses. Second, she was able to bridge subfields by tying together broader questions of comparative politics (such as nationalism, social movements, conflict, and area studies) with questions resonating in international relations (such as comparative foreign policy and international dimensions of conflict).
Gerner's focus on the nexus between quantitative/qualitative as well as comparative/IR propelled her into the world of events data analysis of politics - in particular, conflict and mediation in the Middle East-a field in which she helped pioneer new methods, new theories, and new empirical findings. Along with Philip Schrodt, Gerner developed the Kansas Events Data System (KEDS), an automated content analysis package used to create large amount of events data from machine-readable news sources. While many in international relations had used events data for over 20 years, researchers had been hamstrung by the lack of updated, replicable data sets.

Gerner and the KEDS project were instrumental in making the creation of such data feasible. Yet, a key reason KEDS succeeded was Gerner's contribution of region-specific knowledge. For any quantitative data, validity is the major concern; Gerner's Middle East expertise and her training in IR ensured that the KEDS data was both valid and useful for theory testing. Gerner and Schrodt secured multiple National Science Foundation grants and authored numerous publications in top journals throughout the 1990 s and 2000 s relating to the creation and analysis of events data concerning the Middle East. The substantive topics tackled with this new tool ranged from the development of early warning predictors to studies of reciprocity in conflicts to studies of third party mediation in conflicts. Gerner's recent work grew out of a new project on mediation entitled CAMEO (Conflict And Mediation Event Observations), which uses the successor program to KEDS (named TABARI) to chart conflict mediation by state and substate actors.

Tireless even when dealing with the metastatic cancer that developed in 2002, in 2005 Gerner began work on a threeyear collaborative project (with six colleagues at four universities) funded by the National Science Foundation that utilizes multiple methods to explore the relationship between repression and dissent in the Middle East. In December 2005, she traveled to Palestine and Israel to undertake field research for her portion of the project.

Among her many contributions to her profession over the years, Gerner was active in the Palestinian American Research Center (PARC), the Middle East Studies Association, and numerous 
human rights organizations. She was particularly active within the International Studies Association, serving as vicepresident, two-terms as treasurer, and co-organizer of the 1995 annual meeting. Gerner also served for six years on the editorial committee of Middle East Report, the quarterly published by the Middle East Research and Information Project (MERIP), where she was later elected to the board of directors.

In addition to her original and innovative contributions to the field, Gerner was an outstanding teacher in the classroom-one of the most popular and respected undergraduate teachers at the University of Kansas. She often used case-based teaching methods in her courses and was the author of six case studies for the Institute for the Study of Diplomacy. She was also the recipient of multiple teaching awards, including the prestigious W. T. Kemper Fellowship for Teaching Excellence in the fall of 2000.

Jon Pevehouse University of Wisconsin, Madison Jillian Schwedler University of Maryland, College Park

\section{Deepa Khosla}

Deepa Khosla, a young and vital student of international responses to armed conflict in the Third World, died on November 21,2005 , shortly after beginning a tenure-track position at Memorial University of Newfoundland in St. Johns.

The immediate cause of her death was a brain aneurysm.

Deepa Khosla was born in Uganda in 1964 and, along with her extended family, was among the residents of East Indian descent who were expelled by the Idi Amin regime in 1972. Her family emigrated to Canada later that year. Deepa received her B.A. (1990) and M.A. (1992) degrees in political science from the University of British Columbia where she acquired a strong background in international relations theory and area expertise in Asia. She worked briefly for the Canadian Broadcasting Corporation and then entered the Ph.D. program at the University of Maryland in 1993 with a university fellowship.

In 1997 Deepa received a prestigious Peace Scholar Dissertation Fellowship

\section{Notes}

1. The full report is available at www.cidem. umd.edu, Publications, Peace and Conflict 2005 by Monty G. Marshall and T. R. Gurr. Deepa Khosla is author of Chapter 5, pp. 21-7, and Appendix tables II, 2, and 3. from the U.S. Institute of Peace to pursue her doctoral research. Her central research question was whether and how intervention by foreign powers affected the level of violence in the ethnopolitical wars of the 1980s and 1990s. Her comparative empirical work on this topic was first published in a 1999 article in Third World Quarterly. This presaged her dissertation results which showed, for example, that interventions during the Cold War were more likely to lead to conflict escalation, whereas in the 1990s they were more likely to stabilize or reduce violence. Contrary to prevailing wisdom, she also found that competing interventions had no consistent effect on levels of rebellion.

By the time of her appointment at Memorial University, Deepa had worked for several years as a researcher at the University of Maryland's Center for International Development and Conflict Management (CIDCM), taught at Simon Fraser University, and held a one-year visiting position at Willamette University in Oregon. She also had a dozen publications to her credit plus had presented a half-dozen papers at professional meetings. Two of her contributions merit special attention. In 1995 I asked her to collaborate with me in a comparative study of domestic and international strategies for managing separatist conflicts in Asia, with support from the International Social Science Council's Conflict Early Warning Systems program. Deepa's detailed analysis of four such conflictstwo contained in Tripura and the Philippines, two continuing in Kashmir and Tibet-provided the basis for evaluating the effects of conflict-reducing initiatives taken in each case. We coauthored a lengthy chapter that reported the results of the study in Hayward Alker et al. (eds.), Journeys through Conflict: Narratives and Lessons (Rowman \& Littlefield, 2001). Shortly before she left for Newfoundland she completed a global survey of "Self-Determination Movements and Their Outcomes" that was published in CIDCM's biennial report, Peace and Conflict 2005: A Global Survey of Armed Conflicts, Self-Determination Movements, and Democracy. ${ }^{1}$

Deepa had admirable qualities of persistence, precision, and focus in all her work. As her dissertation advisor and collaborator, I found she worked with close attention to detail and nuanced interpretations. Her early death cut short her plans for a post-doctoral book project on how patterns and outcomes of intervention in armed conflicts are affected by changes in international norms about sovereignty and territorial inviolability.

In the months before her death Deepa asked Memorial University officials for protection against sexual harassment. ${ }^{2}$ In response to her concerns and those raised later by her family, professional colleagues, and the media about her experiences, President Alex Meisen of Memorial University commissioned an external inquiry into the circumstances of her death and, more generally, the status of women students, staff, and faculty at the university. The investigation was conducted by Professor Shirley Katz of York University, a lawyer with extensive experience in harassment and discrimination issues. Professor Katz interviewed many people on and off campus who had some knowledge of these issues and completed her report on August 15, 2006.

Professor Katz's report says that "While some interviewed emphasized a positive environment, many ... reported evidence of a serious malaise and masculine culture." ${ }^{3}$ She made 12 recommendations for dealing with these issues, including the establishment of a crisis and risk management team and a Center for Human Rights and Equity. ${ }^{4}$

As of this writing the full report is being redacted to protect the identity of those interviewed and has not yet been made public. President Meisen has informed the university community that the report shows that everything possible was done for Deepa and that colleagues and administrators acted in good faith. At the same time, he acknowledged problems with the university's procedures and machinery for handling cases of harassment and discrimination, and has promised to implement all 12 recommendations by December 2006.

Those of us who knew and worked with Deepa Khosla hope that her death and the university's response will have lasting benefits for women at Memorial University.

Ted Robert Gurr University of Maryland
2. Described in "The President's Dilemma," p. 8 in Current magazine, www2.currentmag.ca/.

3. The Muse, MUN student newspaper, September 21, 2006, www.themuse.ca/view.php? aid =39373; see also the editorial at www. themuse.ca/view.php?aid=39428.
4. "Dr. Shirley Katz's Investigation into the Employment Experience of Dr. Deepa Khosla and Related Matters," www.mun.ca/marcom/ home/katz_report.php. 